\title{
Health system stewardship in Iran: Far from perfect!
}

\author{
Najmeh Bahmanziari ${ }^{1}$, Amirhossein Takian*1,2,3 (D) \\ Received: 27 Sep 2019 \\ Published: 27 Oct 2020
}

\begin{abstract}
This debate article highlights that to perform efficiently and meaningfully, the structure and organization of a health system need to be adjusted to its philosophy, mission, and expected duties. Development of the required organizational structure, in line with the objectives and strategies of the national health policy are fundamental principles of healthcare stewardship. Despite several reforms and initiatives in the course of the last few decades, the Ministry of Health and Medical Education (MoHME), as the steward of the health system in Iran, has not been performing efficient enough to respond to serious emerging challenges. In order to move in line with sustainable health development agenda and reach universal health coverage (UHC), we advocate fundamental structural and institutional reforms within the MoHME in Iran.
\end{abstract}

Keywords: Health system, Stewardship, Iran

Conflicts of Interest: None declared

Funding: This research has been supported by Tehran University of Medical Sciences and health Services grant (9321460003).

*This work has been published under CC BY-NC-SA 1.0 license.

Copyright $\subseteq$ Iran University of Medical Sciences

Cite this article as: Bahmanziari N, Takian A. Health system stewardship in Iran: Far from perfect!. Med J Islam Repub Iran. 2020 (27 Oct);34:144. https://doi.org/10.47176/mjiri.34.144

\section{Global governance reforms}

To perform efficiently and meaningfully, the structure and organization of a health system need to be adjusted, both proportionately and targeted, to its philosophy, mission, and expected duties. By conservative governments taking the office in both the USA and the UK during the 1980s (1) and following various challenges faced for universal provision of health services, systematic reforms began to shrink the role of government in service provision, while the role of governments in stewardship and policymaking for health increased (1-3). International agenciesthe World Bank (WB) in particular - started to attach new conditions to their loans provided to the member states, and requested them to implement structural reforms towards decentralization and small government $(4,5)$. The motto of national reforms became "steering rather than rowing" (6).

Corresponding author:Dr Amirhossein Takian, takian@tums.ac.ir

1. Department of Healthcare Management and Economics, School of Public Health, Tehran University of Medical Sciences, Tehran, Iran

2. Department of Global Health \& Public Policy, School of Public Health, Tehran University of Medical Sciences, Tehran, Iran

3. Health Equity Research Center (HERC), Tehran University of Medical Sciences, Tehran, Iran
Some established healthcare systems, e.g., the National Health Service (NHS) in the UK, a globally known equitable and efficient healthcare system, began to limit the government's role in reducing the general expenditures and adopted the new public management approach in non-private areas $(7,8)$, defined new financing mechanisms, expanded the role of the private sector in the provision of different non-clinical and then clinical services to promote ownership diversity, and to improve quality of healthcare and decentralization.

At the beginning of the millennium, the ministries of health in many low and middle-income countries (LMICs) were described as predominantly bureaucratic with inefficient performance and hierarchical management (9). With the United Nations' (UN) Millennium Development Goals (MDGs) global agenda, the World Health Organization

$\uparrow$ What is "already known" in this topic:

Despite some reforms and initiatives in the course of last few decades, the MoHME has not been performing efficient enough to respond to serious emerging challenges.

$\rightarrow$ What this article adds:

The MoHME has to undergo fundamental reforms to reduce its size, restructure its organization, and move towards zero conflict of interest and zero-level corruption to reach its optimal status in improving population health in Iran. 
(WHO), WB, and other UN agencies, in collaboration with the governments of LMICs, began to foster the principles of decentralization in many countries. In line with the decentralizing reforms, the beginning of $21^{\text {st }}$ century witnessed a significant increase in both number and type of the nongovernmental organizations (NGOs), both local/national and international as the primary players of development $(97.3 \%$ increase in the number of NGOs with consultative status in the ECOSOC ((United Nations Economic and Social Council), 2000-2014) (10). As a result, civil society became stronger throughout the world and NGOs were granted an increasing role in organizing and offering services, as well as in raising funds and policy-making (11). As a whole, in the course of the past two decades, the civil society organizations (CSO), i.e., NGOs, charity and philanthropist's organizations e.g. Bill and Melinda Gates Foundation, Wellcome Trust and Ford Foundation, have been gradually creating a considerable capacity in the renovation of the governments' structures, serving populations, particularly the deprived groups, and recently policymaking in both high and low-middle income settings (1). Currently, the platform of public-private partnership (PPP) is globally accepted as an effective mechanism for aggregating and concentrating the relative strong points of both sectors in dealing with problems that none can overcome alone (12).

\section{Structural reforms in Iran's health system}

Along with the global community, the governance structure in Iran as a whole, and within the health sector, in particular, have been undergoing various reforms. Since 1926, health system in Iran has been under an assigned ministry, whose name and function have experienced various transformations, i.e., the Ministry of Health and Charities, the Ministry of Health and the Ministry of Health and Wellbeing. Transformed into the Ministry of Health and Medical Education (MoHME) in 1985, a fundamental reform brought the responsible universities from the Ministry of Higher Education under the patronage of the MoHME, while medical education was integrated into healthcare provision. On the basis of the Islamic Republic of Iran's constitution, the government is obliged to provide the healthcare needs of all populations on an equitable basis. The upstream policies (e.g., Mega Health Policies and 6th 5-Year Economic, Social and Cultural Development Plan of The Islamic Republic of Iran) have assigned the MoHME as the steward of the health system. Ever since it was established, the MoHME has been undergoing constant structural and organizational reforms to accommodate various evolving public demands from the emerging Iranian society. The unique governance of the MoHME attributed to the merger of medical education into healthcare service has brought specific institutional challenges and made somewhat controversial structures amenable, not necessarily all have resulted in intended outcomes (13). Notwithstanding, making Food and Drug Organization (FDO) as a quasi-independent organization, followed by the formation of the Deputy for Social Affairs in 2016, as a part of recent Health Transformation Plan (HTP) that began in 2014 to reach universal health coverage (UHC), which was dissolved again in February 2019.

Development of the required organizational structure in line with the objectives and strategies of the national health policy are fundamental principles of healthcare stewardship (14). Appropriate structure that is adjusted to the mission of any organization lies at the heart of institutional mapping, whose effects on the performance, quality of resource allocation and enhancement of organizational accomplishments is well-evident (15-18). In the context of the MoHME in Iran, investigation of more than three decades of the structural changes in line with the public choice theory reveals that conflict of interest and weak evidence-informed decision-making have fueled some key decisions in resource allocation, the appointment of high-level managers, and initiation of some reforms. For instance, accreditation of medical universities, public hospitals, purchaserprovider split (19), and prioritization of some initiatives over alternatives might not have precisely followed public interests and needs, and may have failed as a result.

The need for major organizational reforms in the MoHME has been emphasized by many high-rank officials, i.e., the previous and present ministers, who criticized the MoHME for massive bureaucracy, overlapping responsibilities and weak coordination among its many (eight at the moment) deputies, all of which have contributed to inefficiency. In addition, the MoHME has not been performing efficient enough to respond to serious emerging challenges, e.g., the ongoing COVID-19 crisis (20), aging population, the epidemiological transition towards the huge burden of non-communicable diseases (NCDs), unfair international sanctions against Iran that is threatening the country's ability to produce medicines, unsustainable fiscal space (21), and cultural barriers to foster self-care, among others. The government, if it enjoys the highest levels of political support, needs to revise its approach to accommodate the global evidence to tailor appropriate decentralization, reduce the size of the MoHME and rearrange it to the highlevel policy-making body than the micromanager and provider of services. More importantly, the MoHME needs to create an effective platform to engage meaningfully with the private sector, foster and operationalize inter-sectoral collaboration and public-private partnership, and overcome its longstanding conflicts of interest in health policy-making, all in line with upstream policies and laws, along with its rather long and winding road to reduce inefficiency, as well as enhancing transparency and responsiveness of the health system in Iran. It is evident that the existing laws/legislations and upstream policies clearly underscore the stewardship role of the MoHME, as well as the role of decentralization and downsizing the government through various means. This include but not limited to the establishment of quasi-dependent organizations under the MoHME's supervision, fostering meaningful cooperation with the non-governmental sector, and increasing government's authority for strong monitoring and evaluation of healthcare centers based on defined standards and criteria. This will in turn enhance quality, reduce inefficiency, and increase public satisfaction. Despite some decentralization initiatives in the 
course of past two decades, e.g., partial privatization of selected primary healthcare services in some areas, the formation of boards of trustees in the universities of medical sciences and autonomy of teaching hospitals, such experiences have not been successful enough to increase the efficiency of the Iranian health system and reduce the paralyzing conflict of interest meaningfully (22-24). Indeed, various prerequisites need to be met to reach optimal status.

\section{Conclusion}

In line with the global spirit of small and effective government, Iran enjoys strong laws and upstream policies to support decentralization, enhance health system efficiency and improve public satisfaction with the health system. As the steward of the health system, the MoHME should steer, not row, the entire health system. The current structure and organization of the MoHME have made it incapable of leading the health system towards its ultimate goals in Iran, namely: efficient, equitable, affordable and universal healthcare for all populations in need. Along the way to reach sustainable health development, including attainment of universal health coverage and leaving no one behind, we call upon the MoHME to undergo fundamental reforms to reduce its size, restructure its organization, and move towards zero conflict of interest and zero-level corruption, ultimately.

\section{Conflict of Interests}

The authors declare that they have no competing interests.

\section{References}

1. Buse K, Mays N, Walt G. Making Health Policy (Understanding Public Health). 2nd ed. England: Open University Press; 2012.

2. Roberts MJ, Hsiao W, Berman P, Reich MR. Getting Health Reform Right: A guide to Improving Performance and Equity. 1st ed. Oxford: Oxford University Press; 2004.

3. Simonet D. The New Public Management Theory and European HealthCare Reforms. Can Public Admin. 2008;51(4):617-35.

4. Litvack J, Ahmad J, Bird R. Rethinking Decentralization in Developing Countries. Washington, D.C: World Bank; 1998. Report No: 21491.

5. Silverman JM. Public Sector Decentralization: Economic Policy and Sector Investment Programs. Washington, DC: World Bank; 1992. Report No: WTP188.

6. Osborne D, Gaebler T. Reinventing Government: How the Entrepreneurial Spirit Is Transforming the Public Sector. New York: Addison-Wesley; 1992.

7. Simonet D. The New Public Management Theory in the British Health Care System: A Critical Review. Adm Soc. 2013;47(7):1-25.

8. Simonet D. Assessment of New Public Management in Health Care: The French Case. Health Res Policy Syst. 2014;12(1):57.

9. Mills AJ, Ranson MK. The Design of Health Systems. In: Merson MH, Black RE, Mills AJ, editors. International Public Health: Disease, Programs, Systems and Policies. 2nd ed. Boston: Jones and Bartlett; 2006. pp. 513-47.

10. Emmrich D, Kleinschmidt K. NGOs in the 21st Century: The Opportunities Presented by Digitalization and Globalization. Munich: Dr. Wieselhuber \& Partner GmbH Unternehmensberatung; 2017.

11. Peterson MA. Motivation, Mobilisation and Monitoring: The Role of Interest Groups in Health Policy. J Health Polit Policy Law. 1999;24(3):415-20.

12. World Health Organization. WHO's Engagement with Non-State Actors: World Health Organization; 2016 [cited 2019. Available from: http://www.who.int/about/collaborations/non-state-actors/en/.

13. Doshmangir L, Bazyar M, Majdzadeh R, Takian A. So Near, So Far: Four Decades of Health Policy Reforms in Iran, Achievements and
Challenges. Arch Iran Med. 2019 Oct 1;22(10):592-605.

14. World Health Organization. Everybody's Business: Strengthening Health Systems to Improve Health Outcomes: WHO's Framework for Action. Geneva: World Health Organization; 2007.

15. Seitio-Kgokgwe O, Gauld RDC, Hill PC, Barnett P. Redesigning a Ministry of Health's Organizational Structure: Exploring Implementation Challenges Through Botswana's Experiences. Int J Health Plann Manage. 2016;31(2):191-207.

16. Rezaian A. Principles of Organization and Management. 16th ed. Tehran: SAMT; 2013.

17. Burton RM, Obel B, DeSanctis G. Organizational Design: A Step-byStep Approach 2nd ed. New York: Cambridge University Press; 2011.

18. Arabi SM. Organizational Structure Design. 2nd ed. Tehran: Cultural Research Bureau; 1995.

19. Takian A, Rashidian A, Doshmangir L. The Experience of PurchaserProvider Split in the Implementation of Family Physician and Rural Health Insurance in Iran: An Institutional Approach. Health Policy Plan. 2015;30(10):1261-71.

20. Raoofi A, Takian A, Akbari Sari A, Olyaeemanesh A, Haghighi H, Aarabi M. COVID-19 pandemic and comparative health policy learning in Iran. Arch Iran Med. 2020;23(4):220-234.

21. Takian A, Raoofi A, Kazempour-Ardebili S. COVID-19 battle during the toughest sanctions against Iran. Lancet. March 17, 2020 https://doi.org/10.1016/ S0140-6736(20)30668-1.

22. Doshmangir L, Rashidian A, Ravaghi H, Takian A, Jafari M. The Experience of Implementing the Board of Trustees' Policy in Teaching Hospitals in Iran: An Example of Health System Decentralization. Int J Health Policy Manag. 2014;4(4):207-16.

23. Heshmati B, Joulaei H. Iran's Health-care System in Transition. Lancet. 2016;387(10013):29-30.

24. Doshmangir L, Rashidian A, Jafari M, Takian A, Ravaghi H. Opening the Black Box: The Experiences and Lessons From the Public Hospitals Autonomy Policy in Iran. Arch Iran Med. 2015;18(7):416-24. 